\title{
Erratum: Factors influencing agbiotech adoption and development in sub-Saharan Africa
}

Obidimma C Ezezika, Abdallah S Daar, Kathryn Barber, Justin Mabeya, Fiona Thomas, Jennifer Deadman, Debbie Wang \& Peter A Singer Nat. Biotechnol. 30, 38-40 (2012); published online 9 January 2012

In the version of this article published in print, the affiliations were omitted. The error was corrected before online publication in the HTML and PDF versions of the article.

\section{Erratum: Amelioration of sepsis by inhibiting sialidase-mediated disruption of the CD24-SiglecG interaction}

Guo-Yun Chen, Xi Chen, Samantha King, Karen A Cavassani, Jiansong Cheng, Xincheng Zheng, Hongzhi Cao, Hai Yu, Jingyao Qu, Dexing Fang, Wei Wu, Xue-Feng Bai, Jin-Qing Liu, Shireen A Woodiga, Chong Chen, Lei Sun, Cory M Hogaboam, Steven L Kunkel, Pan Zheng \& Yang Liu Nat. Biotechnol. 29, 428-435 (2011); published online 6 May 2011; corrected after print 18 January 2012

In the version of this article initially published, a line in the abstract read, "repressed by the t interaction...." It should have read, "repressed by the interaction..." The error has been corrected in the HTML and PDF versions of the article.

\section{Corrigendum: Industry continues dabbling with open innovation models}

Cormac Sheridan

Nat. Biotechnol. 29, 1063-1065 (2011); published online 8 December 2011; corrected after print 8 February 2012

In the version of this article initially published, Richard Anderson is named incorrectly and so is his affiliation as director of the Initiative for Open Innovation. The source's correct name is Richard Jefferson and he is founder and CEO of Cambia, a not-for-profit biotech research institute based at the Queensland University of Technology, in Brisbane, Australia. The error has been corrected in the HTML and PDF versions of the article.

Corrigendum: FDA panel votes to pull Avastin in breast cancer, again

Mark Ratner

Nat. Biotechnol. 29, 676 (2011); published online 5 August 2011; corrected after print 8 February 2012

In the version of this article initially published, only "ovarian and small cell lung cancer" were said to be among Avastin's current FDA-approved uses. In the US, Avastin is currently approved for advanced colon, non-small cell lung, glioblastoma and kidney cancers. FDA withdrew Avastin's breast cancer approval in November 2011 (Nat. Biotechnol. 30, 6 (2012). The error has been corrected in the HTML and PDF versions of the article.

\section{Corrigendum: Chinese vaccine developers gain WHO imprimatur}

Hepeng Jia \& Karen Carey

Nat. Biotechnol. 29, 471-472 (2011); published online 7 June 2011; corrected after print 8 February 2012

In the version of this article originally published, in Table 1, Sinovac Biotech was described as having been acquired by Novartis in March. Novartis acquired a different company, Tianyuan, as stated later in the article.

\section{Corrigendum: Intellectual property, technology transfer and manufacture of low-cost HPV vaccines in India}

Swathi Padmanabhan, Tahir Amin, Bhaven Sampat, Robert Cook-Deegan \& Subhashini Chandrasekharan

Nat. Biotechnol. 28, 671-678 (2010); published online 8 July 2010; corrected after print 8 February 2012

In the version of this article initially published, on p. 671, column 2, the authors state: "Merck has donated three million doses of Gardasil to the Program for Appropriate Technology in Health (PATH) for demonstration trials ${ }^{14}$. Its Gardasil Access Program aims to extend this support to eight LMCs ${ }^{15}$ " It should have read: "Merck donated about 130,000 doses to PATH for demonstration studies in India, Peru and Vietnam ${ }^{14}$. Through the Gardasil Access Program, Merck aims to extend its support to LMCs and has pledged to make 3 million doses of vaccine available to eligible countries ${ }^{15}$ ". In addition, reference 14 should have been Tsu, V. PATH/Seattle, personal communication (2011), rather than Harner-Jay et al. J. Pharm. Sci. (2008). 